\title{
Anterior migration of asteroid hyalosis due to aqueous misdirection: asteroids in the wrong orbit
}

\author{
Arjun Desai, ${ }^{1}$ Hrishikesh Kaza, ${ }^{1}$ Brijesh Takkar, ${ }^{1,2}$ Nikhil Choudhari ${ }^{3}$
}

${ }^{1}$ Smt Kanuri Santhamma Centre for Vitreoretinal Diseases, LV Prasad Eye Institute, Hyderabad, Telangana, India

${ }^{2}$ Indian Health Outcomes, Public Health and Economics Research (IHOPE) Centre, LV Prasad Eye Institute, Hyderabad, India ${ }^{3}$ Glaucoma Services, LV Prasad Eye Institute, Hyderabad, Telangana, India

Correspondence to Dr Brijesh Takkar; britak.aiims@gmail.com

Accepted 26 August 2021

\section{DESCRIPTION}

A 70-year-old gentleman presented with vision loss in his left eye (OS) following an uncomplicated phacoemulsification surgery with good postoperative vision (20/20, N6). He had developed redness and severe pain in his operated eye with loss of vision 2 months after the surgery. He was treated as acute glaucoma by the operating surgeon with topical and systemic antiglaucoma medication, and referred for sudden occurrence of exudates in the anterior chamber (AC).

On examination, OS distance visual acuity was hand motion close to face and intraocular pressure (IOP) was $35 \mathrm{~mm} \mathrm{Hg}$. The eye was congested with both microcystic and stromal corneal oedema. The $\mathrm{AC}$ was flat with prominent areas of peripheral iridocorneal touch. There was a striking presence of multiple large clumps of yellow crystalline deposits in the AC (figure 1). The intraocular lens (IOL) could be visualised, but the fundus was not seen. OS B-scan ultrasonography showed few dot-like echoes in the vitreous cavity with a grossly attached retina (figure 2A). Ultrasound biomicroscopy showed shallow AC centrally, while it was flat peripherally (figure 2B). The right eye was unremarkable on examination. Systemic evaluation by a physician was also within normal limits.

Based on these findings, the patient was diagnosed to have malignant glaucoma with a possible migration of asteroid hyalosis (AH) into the AC. Chronic delayed endophthalmitis and masquerade syndromes were also considered as other unlikely differential diagnoses due to the absence of keratic precipitates and AC reaction, absence of vitreous echoes on B-scan ultrasonography (figure 2A) and absence of mass lesion/abscess in the ciliary sulcus on ultrasound biomicroscopy (figure 2B). OS AC wash and tap, vitreous biopsy and

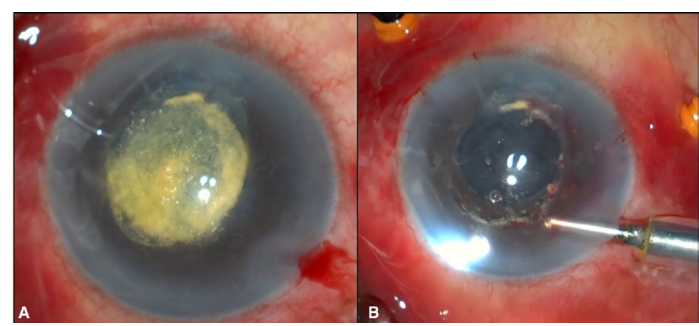

Limited 2021. No commercial re-use. See rights and permissions. Published by BMJ.

To cite: Desai $A$, Kaza $\mathrm{H}$ Takkar $\mathrm{B}$, et al. BMJ Case Rep 2021;14:e246441 doi:10.1136/bcr-2021246441

Figure 1 (A) Intraoperative photograph of left eye showing the presence of yellowish crystalline deposits in the anterior chamber obscuring the visual axis. (B) Intraoperative photograph of left eye showing the anterior chamber cleared of the anterior migrated

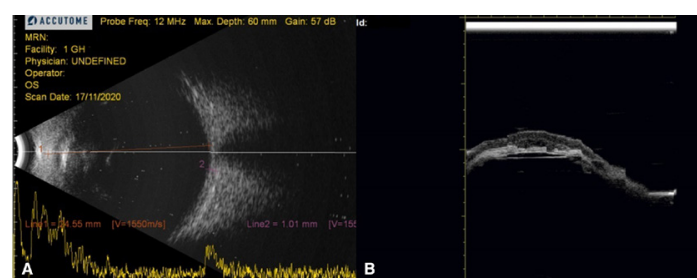

Figure 2 (A) Preoperative B-scan ultrasonography (axial scan) of the left eye showing very few dotlike echoes in the vitreous cavity. (B) Ultrasound biomicroscopy image of the left eye demonstrating a shallow anterior chamber centrally and flat peripherally.

irido-zonulo-hyaloido-vitrectomy were performed (figure 1). Intraoperatively, the AC deposits were found to be dense and were cleared with the help of the vitrectomy cutter. Few refractile crystals were seen in the vitreous cavity too apart from total glaucomatous optic atrophy and grossly normal retina. The posterior capsule was intact and the IOL wellcentred. On day 1 postoperatively, OS IOP had dropped to $17 \mathrm{~mm} \mathrm{Hg}$ with a well-formed AC. On follow-up, OS continued to have low vision and the AC remained stable, while the biopsy was negative for micro-organisms/malignant cells.

To the best of our knowledge, this is the third such case, where $\mathrm{AH}$ has migrated into the $\mathrm{AC}$ following an uncomplicated cataract surgery. In the previous reported cases, cataract surgery had been done much prior (more than 7 years ago) while one had a secondary IOL placement, with those patients being considered to have metastatic deposits. ${ }^{1}$ We believe that malignant glaucoma and the misdirected flow of ocular fluid led to migration of the $\mathrm{AH}$ into the $\mathrm{AC}$, forcing the crystals to prolapse through the zonules. While anterior chamber cholesterosis is known in Coats disease, ${ }^{2} 3$ anterior migration of $\mathrm{AH}$ is rare. ${ }^{145}$ Synchysis scintillans is a close differential of $\mathrm{AH}$ and it is known to cause anterior cholesterosis. However, absence of signs of

\section{Learning points}

Even in the absence of posterior capsule defects or zonular weakness, anterior migration of degenerated vitreous contents is possible, in this case triggered by coexisting malignant glaucoma. asteroid hyalosis. 
prior ocular inflammation or haemorrhage along with unilateral presence of crystals make it unlikely.

Contributors $A D$ was responsible for patient care, acquiring and editing the ophthalmic images, and writing the manuscript. BT was involved in the surgical management of the patient and final editing of the manuscript. He conceptualised the manuscript. HK and NC were involved in patient care and editing the manuscript.

Funding The authors have not declared a specific grant for this research from any funding agency in the public, commercial or not-for-profit sectors.

Competing interests None declared.

Patient consent for publication Obtained.
Provenance and peer review Not commissioned; externally peer-reviewed.

\section{REFERENCES}

1 Shields CL, Romanelli-Gobbi M, Lally SE, et al. Vitreous asteroid hyalosis prolapse into the anterior chamber simulating iris metastasis. Middle East Afr J Ophthalmol 2012;19:346-8.

2 Stacey AW, Borri M, Francesco SD, et al. A case of anterior chamber cholesterolosis due to coats' disease and a review of reported cases. Open Ophthalmol J 2016;10:27-32.

3 Mittal K, Ningombam A, Chawla R, et al. Refractile particles in the anterior chamber of an eye: a rare case. J Appl Lab Med 2019;4:464-7.

4 Jones WL. Asteroid hyalosis in the anterior chamber. J Am Optom Assoc 1980;51:66.

5 Doshi S, Pathengay A, Sane S, et al. Asteroid hyalosis prolapse in the anterior chamber after cataract surgery. BMJ Case Rep 2019:12:e230076.

Copyright 2021 BMJ Publishing Group. All rights reserved. For permission to reuse any of this content visit

https://www.bmj.com/company/products-services/rights-and-licensing/permissions/

BMJ Case Report Fellows may re-use this article for personal use and teaching without any further permission.

Become a Fellow of BMJ Case Reports today and you can:

- Submit as many cases as you like

- Enjoy fast sympathetic peer review and rapid publication of accepted articles

- Access all the published articles

Re-use any of the published material for personal use and teaching without further permission

Customer Service

If you have any further queries about your subscription, please contact our customer services team on +44 (0) 2071111105 or via email at support@bmj.com.

Visit casereports.bmj.com for more articles like this and to become a Fellow 